\title{
Operations Research Problems and Data Envelopment Analysis in Agricultural Land Processing - A Review
}

DOI: 10.7595/management.fon.2020.0016

\begin{abstract}
:
Research Question: This paper aims at specifying the contribution of operations research (OR) methods and techniques to agricultural land processing. Motivation: Agricultural production is performed on an agricultural land, which has to be exploited in the best possible way, given the increasing human population and the limited availability of the land. Considering the importance of this issue, a large number of research studies dealing with problems in agriculture can be found in the literature, and many of these problems are solved by OR methods and techniques. However, to our knowledge, there are no review papers that deal with this specific area, so the main motivation is to provide a detailed review of selected OR methods application in the agricultural land processing area. Idea: The core idea behind this research is to perceive a real impact of OR methods and techniques implementation in the agricultural land processing. The research is based on detailed literature review for the period 2014-2019 and performed statistics involving publication by year, publication by journal and statistics involving keywords in articles. Data: The review was conducted using online repositories of the papers published in SCl and SCle journals with impact factors in the period from 2014-2019. Tools: Analyzed papers are divided into three groups according to the OR method applied: linear optimization problems, DEA method and other OR methods (non linear, multicriteria, mixed integer programming, dynamic programming). Papers within the groups are analyzed according to the type of problems solved. Statistical analyses of all collected data were used to get a good insight into the applications of operations research problems and data envelopment analysis in agricultural land processing. Findings: The number of published papers in this specific area has a growing trend over the observed years (with some minor decrease in 2016 and 2019 in comparison with the previous year). All of the articles are related to specific application of the given methods to solving problems in the agricultural land processing, and this is the reason for many different keywords appearing in the articles. Some very important keywords such as "operations research" or "OR" does not appear in any article as a keyword. Inclusion of such common keywords may result in a faster search in repositories of all articles. Contribution: The primary contribution of this paper is a detailed review of application of linear optimization, data envelopment analysis and other OR methods in agricultural land processing in the period 2014-2019.
\end{abstract}

Keywords: Agriculture, processing of agricultural land, data envelopment analysis (DEA), operations research, OR methods

JEL Classification: Q15, C44, C67

\section{Introduction}

The growth of human population and industrial production consequently leads to increased pollution, land degradation, habitat fragmentation and unsustainable consumption, and due to extensive use, arable land is of poorer quality, getting more and more polluted, and consequently the availability is reduced. Effective agriculture management is necessary to maximize land productivity at this moment and in the future (Andric Gusavac \& Savic, 2019). 
Agricultural problems can be solved by various operations research methods and these methods have helped over the past decades to understand the complex functioning of agricultural systems, as well as to manage these systems in an efficient way (Weintraub \& Romero, 2006).

Problems related to the agricultural land processing are very common in the literature. Problems related to the: crop diversification, crop planning and crop rotation are solved. Decisions are made regarding the type of crops to be grown in the planning horizon (plant different crop in each or every couple of periods). Problems of this kind are often modelled by linear programming and mixed linear programming (Boboev, Djanibekov, Bekchanov, Lamers \& Toderich, 2019; Albornoz, Nanco \& Saez, 2019; Aljanabi, Mays \& Fox, 2018). Problems in choosing farmland / tillage strategies at farm level to avoid soil degradation are also modelled by linear (Boboev et al., 2019). and mixed linear programming (Bavorova, Imamverdiyev \& Ponkina, 2018). For all these types of problems, the area where the land is located - arid or not, the availability of irrigation water, the availability of energy and all other resources, etc., is taken as the decision factor. Regarding the problems of efficiency and technical efficiency of agriculture, the DEA method is applied (Muhtarom, Haryanto \& Istifadah, 2019; Li, Jiang, Mu \& Yu, 2018).

A review of the literature in the last five years reveals that the most common problems in the field of agriculture, which are solved by operations research methods and techniques, are related to the processing of agricultural land. Papers published in SCI and SCle journals according to KOBSON (Kobson, 2019) are presented in this paper. The number of papers dealing with the implementation of operational research in the field of agriculture in the last five years is more than 80 , and they are modelled by linear, nonlinear, mixed integer programming, dynamic programming, multi-criteria models and Data Envelopment Analysis (DEA). A very large number of problems is successfully modelled by linear programming (LP), and these papers are presented in the third chapter of this paper. The DEA method is widely used for efficiency assessment in the agricultural chapter, and 21 papers regarding agricultural land related problems solved by DEA method are presented in chapter 4. Agricultural land processing problems solved by other operations research (OR) methods and techniques are presented in chapter 5 of this paper.

The next section provides a series of selected statistics involving the articles and journals within our literature review.

\section{Publication Statistics}

\subsection{Statistics involving publications by year}

Fig. 1 shows the distribution of OR articles in agricultural land processing published by year.

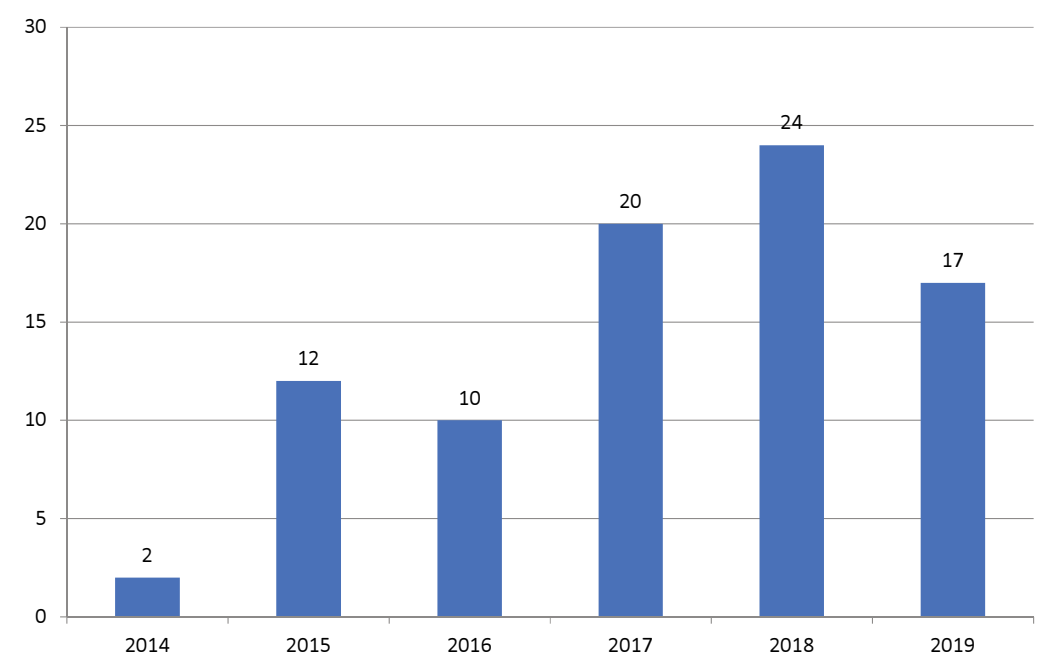

Figure 1: Distribution of agricultural land processing articles by year

Note that the number of papers is growing over the years, with some minor decrease in 2016 and 2019. 


\subsection{Statistics involving publications by journal}

Table 1 lists 13 journals that have published the largest number of OR and agriculture related papers in the past 5 years. Journals such as Computers and Electronics in Agriculture, Land Use Policy, Sustainability (Switzerland) and Agricultural Systems are the most utilized journals. The scope of these journals falls within the fields of operations research and management science combined with agriculture, so these results are expected.

Table 1: Journals that have published the greatest number of agricultural land processing articles

\begin{tabular}{|l|l|c|c|}
\hline No. & \multicolumn{1}{|c|}{ Journal } & $\begin{array}{c}\text { Number of } \\
\text { articles }\end{array}$ & \% of articles \\
\hline 1 & Computers and Electronics in Agriculture & 10 & 11.76 \\
2 & Land Use Policy & 6 & 7.06 \\
3 & Sustainability (Switzerland) & 6 & 7.06 \\
4 & Agricultural Systems & 5 & 5.88 \\
5 & Agricultural Economics (Czech Republic) & 4 & 4.71 \\
6 & Journal of Cleaner Production & 4 & 4.71 \\
7 & Journal of Environmental Management & 3 & 3.53 \\
8 & Journal of Irrigation and Drainage Engineering & 3 & 3.53 \\
9 & Energy & 2 & 2.35 \\
10 & Environment, Development and Sustainability & 2 & 2.35 \\
11 & Environmental Science and Pollution Research & 2 & 2.35 \\
12 & Pakistan Journal of Agricultural Sciences & 2 & 2.35 \\
13 & Other journals (36 journals) & $1(36)$ & $1.18(42.35)$ \\
\hline \multicolumn{2}{r}{ Total } & 85 & 100 \\
\hline
\end{tabular}

\subsection{Statistics involving keywords used in articles}

Regarding the papers of linear optimization problems in agricultural land processing, a total of 165 keywords are detected (average of 5.89 keywords per article). Most commonly utilized keywords in this area are listed in table 2. Only keywords that appear 3 or more times are listed.

Table 2: Keywords commonly used in LP/Agricultural land processing articles

\begin{tabular}{|l|l|c|}
\hline No. & \multicolumn{1}{|c|}{ Journal } & No. of articles \\
\hline 1 & Crop (crop rotation, crop production, crop planning, crop & 13 \\
2 & residues, crop diversification) & \\
3 & Linear programming & 5 \\
4 & Environmental impact & 5 \\
5 & MILP & 3 \\
6 & Conjunctive use & 3 \\
7 & Harvest & 3 \\
8 & Optimisation & 3 \\
\hline
\end{tabular}

Although all of these articles are contributions of OR methods and techniques in specific area (agricultural land production), the keyword "operations research in agriculture" appears only in one article.

Most commonly used keywords in DEA applications in agricultural land processing are listed in table 3. A total of 122 keywords are detected in this area (average of 4.88 keywords per article). Only the keywords that appear 3 or more times are listed.

Table 3: Keywords commonly used in LP/Agricultural land processing articles

\begin{tabular}{|l|l|c|}
\hline No. & \multicolumn{1}{|c|}{ Journal } & No. of articles \\
\hline 1 & Data envelopment analysis & 13 \\
2 & Agriculture & 8 \\
3 & Technical efficiency & 5 \\
4 & Eco-efficiency & 5 \\
5 & Sustainability & 3 \\
6 & Energy use efficiency & 3 \\
\hline
\end{tabular}


When we list the keywords used in OR methods (beside LP and DEA), we can notice (table 4) that here we have more matching keywords than in LP and DEA applications. Like in previous cases, only the keywords that appear 3 or more times are listed. Most commonly used keywords are "agriculture", "multi criteria analysis" and "optimisation". A total of 236 keywords are detected in this area (average of 6.74 keywords per article).

Table 4: Keywords commonly used in DEA/Agricultural land processing articles

\begin{tabular}{|l|l|c|}
\hline No. & \multicolumn{1}{|c|}{ Journal } & No. of articles \\
\hline 1 & Data envelopment analysis & 13 \\
2 & Agriculture & 8 \\
3 & Technical efficiency & 5 \\
4 & Eco-efficiency & 5 \\
5 & Sustainability & 3 \\
6 & Energy use efficiency & 3 \\
\hline
\end{tabular}

\section{Overview of Linear Optimization Problems in Agricultural Land Processing}

Operations research methods and techniques are extensively applied to solve problems in the field of agriculture. Modelling, as a basic tool in the science of agricultural systems, has been developed by scientists working in various fields over the past six decades (Jones et al., 2017).

Table 5 shows the papers dealing with problems related to agricultural land processing, which are solved by linear programming. A brief description of the problem and a formulated model for solving the problem is given for each paper.

Table 5: Overview of linear optimization problems in agricultural land processing (adapted from Andric Gusavac \& Savic, 2019)

\begin{tabular}{|l|l|c|}
\hline No. & \multicolumn{1}{|c|}{ Journal } & No. of articles \\
\hline 1 & Data envelopment analysis & 13 \\
2 & Agriculture & 8 \\
3 & Technical efficiency & 5 \\
4 & Eco-efficiency & 5 \\
5 & Sustainability & 3 \\
6 & Energy use efficiency & 3 \\
\hline
\end{tabular}

Many of the agricultural problems modelled as linear programming problem are solved by exact methods (Cid-Garcia \& Ibarra-Rojas, 2019; Ahodo et al., 2019; Boboev et al., 2019; Kiryluk-Dryjska \& Beba, 2018; Smith et al., 2018; Bavorova et al., 2018; Zhang et al., 2017; Singh, 2017; Capitanescu et al., 2017; Pieralli, 2017; Nidumolu et al., 2016; Rocco \& Morabito, 2016; Galan-Martin et al., 2015; Naudin et al., 2015; Das et al., 2015; Singh, 2015).

Problems related to the processing of agricultural land are very common in the literature: division of arable land, crop planning, and crop rotation are solved. Crop rotation and crop planning are type of problems that are solved by linear programming in 13 analysed articles (48,15\%). Problems of division of arable land and resource planning include $22.22 \%$ ( $11.11 \%$ of articles each), and two articles $(7.41 \%)$ deal with harvesting problems; the same number of articles is for conversion of land or conversion of agriculture production (Fig. 2).
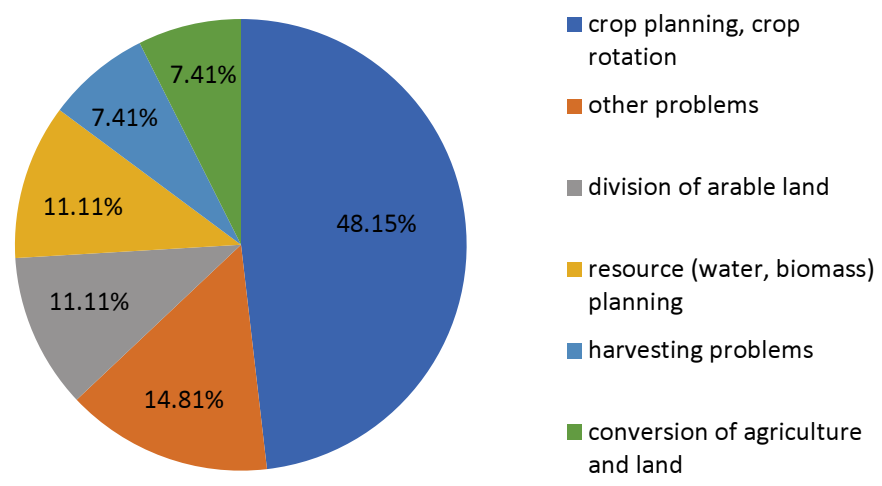

Figure 2: Distribution of agricultural problem types solved by LP 


\section{Overview of DEA Problems in Agricultural Land Processing}

The most commonly used technique for the problems of evaluation and comparative analysis of efficiency in agriculture is the mathematical programming technique - Data Envelopment Analysis (DEA) (Charnes, Cooper \& Rhodes, 1978).

Papers dealing with the problems of evaluation and comparative analysis of agricultural efficiency are shown in Table 6. For each reference a brief description of the problem is given.

Table 6: Overview of DEA problems in agricultural land processing (adapted from Andric Gusavac \& Savic, 2019)

\begin{tabular}{|c|c|c|}
\hline Reference & Problem & Model \\
\hline Masuda, 2019 & $\begin{array}{l}\text { expanding the size of rice farms and impact on eco-efficiency of rice } \\
\text { production }\end{array}$ & $\begin{array}{l}\text { DEA and LCA (life } \\
\text { cycle assessment) }\end{array}$ \\
\hline $\begin{array}{l}\text { Djokic, Jurjevic, } \\
\text { Popovic \& Savic, } 2019\end{array}$ & $\begin{array}{l}\text { comparison of organic and conventional soybean production } \\
\text { systems }\end{array}$ & DEA \\
\hline $\begin{array}{l}\text { Guth \& Smędzik- } \\
\text { Ambroży, } 2019\end{array}$ & technical efficiency of different types of agricultural production & DEA \\
\hline $\begin{array}{l}\text { Grados \& Schrevens, } \\
2019\end{array}$ & $\begin{array}{l}\text { assessment of the environmental impact of potato production and } \\
\text { assessment of the eco-efficiency of agricultural systems }\end{array}$ & DEA \\
\hline Muhtarom et al., 2019 & efficiency and productivity analysis of the agricultural production & DEA \\
\hline $\begin{array}{l}\text { Rybaczewska- } \\
\text { Błazejowska \& } \\
\text { Gierulski, } 2018\end{array}$ & assessment of th eco-efficiency of the agricultural production in EU & DEA \\
\hline Li et al., 2018 & $\begin{array}{l}\text { technical efficiency evaluation and energy savings potential in China } \\
\text { agricultural sector }\end{array}$ & DEA \\
\hline $\begin{array}{l}\text { Khoshroo, Izadikhah \& } \\
\text { Emrouznejad, } 2018\end{array}$ & $\begin{array}{l}\text { energy efficiency of the turnip production and reduction of } \mathrm{CO}_{2} \\
\text { emission }\end{array}$ & DEA \\
\hline $\begin{array}{l}\text { Moutinho, Madaleno, } \\
\text { Macedo, Robaina \& } \\
\text { Marques, } 2018\end{array}$ & efficiency of the European agricultural sector & DEA \\
\hline Masuda, 2018 & energy efficiency of intensive rice production in Japan & DEA \\
\hline Staniszewski, 2018 & $\begin{array}{l}\text { assessing sustainable agriculture intensification in the European } \\
\text { Union }\end{array}$ & DEA \\
\hline Abbas et al., 2018 & $\begin{array}{l}\text { new approach for energy efficiency assessment and sustainability of } \\
\text { wheat production }\end{array}$ & DEA \\
\hline $\begin{array}{l}\text { Godoy-Durán, } \\
\text { Galdeano- Gómez, } \\
\text { Pérez-Mesa \& Piedra- } \\
\text { Muñoz, } 2017\end{array}$ & eco-efficiency assessment of small farms engaged in horticulture & DEA \\
\hline $\begin{array}{l}\text { Khanjarpanah, } \\
\text { Pishvaee \& } \\
\text { Seyedhosseini, } 2017\end{array}$ & $\begin{array}{l}\text { evaluation the candidate locations efficiency for switchgrass } \\
\text { cultivation used for biofuel production }\end{array}$ & $\begin{array}{l}\text { risk averse cross- } \\
\text { efficiency DEA mode }\end{array}$ \\
\hline $\begin{array}{l}\text { Toma, Miglietta, Zurlini, } \\
\text { Valente \& Petrosillo, } \\
2017\end{array}$ & evaluation of agricultural efficiency in European Union & bootstrap-DEA \\
\hline $\begin{array}{l}\text { Vlontzos, Niavis \& } \\
\text { Pardalos, } 2017\end{array}$ & $\begin{array}{l}\text { assessment of the sustainability of the agricultural sector using the } \\
\text { eco-efficiency index }\end{array}$ & DEA \\
\hline Pokhrel \& Soni, 2017 & $\begin{array}{l}\text { analysis of the energy, environmental and financial performances of } \\
\text { different rice-based cropping systems }\end{array}$ & DEA \\
\hline Murtaza \& Thapa, 2017 & assessment of the technical efficiency in apple production sector & DEA \\
\hline $\begin{array}{l}\text { Atici \& Podinovski, } \\
2015\end{array}$ & $\begin{array}{l}\text { evaluation of the efficiency of units of different specialization in the } \\
\text { agricultural sector }\end{array}$ & DEA \\
\hline $\begin{array}{l}\text { Gadanakis, Bennett, } \\
\text { Park \& Areal, } 2015\end{array}$ & $\begin{array}{l}\text { assess sustainable intensification at a farm level (identification of } \\
\text { appropriate production technologies and practices) }\end{array}$ & DEA \\
\hline $\begin{array}{l}\text { Nowak, Kijek \& } \\
\text { Domańska, } 2015\end{array}$ & $\begin{array}{l}\text { measurement of the technical efficiency of agriculture in the } \\
\text { European Union countries }\end{array}$ & DEA \\
\hline Kocisova, 2015 & $\begin{array}{l}\text { measurement of the relative technical efficiency of agriculture in the } \\
\text { European Union }\end{array}$ & DEA \\
\hline Souza \& Gomes, 2015 & assessment of the economic efficiency of agriculture & DEA \\
\hline $\begin{array}{l}\text { Mirza, Najam, Mehdi \& } \\
\text { Ahmad, } 2015\end{array}$ & evaluation of technical efficiency of wheat farms & DEA \\
\hline
\end{tabular}


It is interesting to distinguish different types of efficiency determined by the DEA method in the agricultural land processing area. This distribution is presented in Fig. 3.

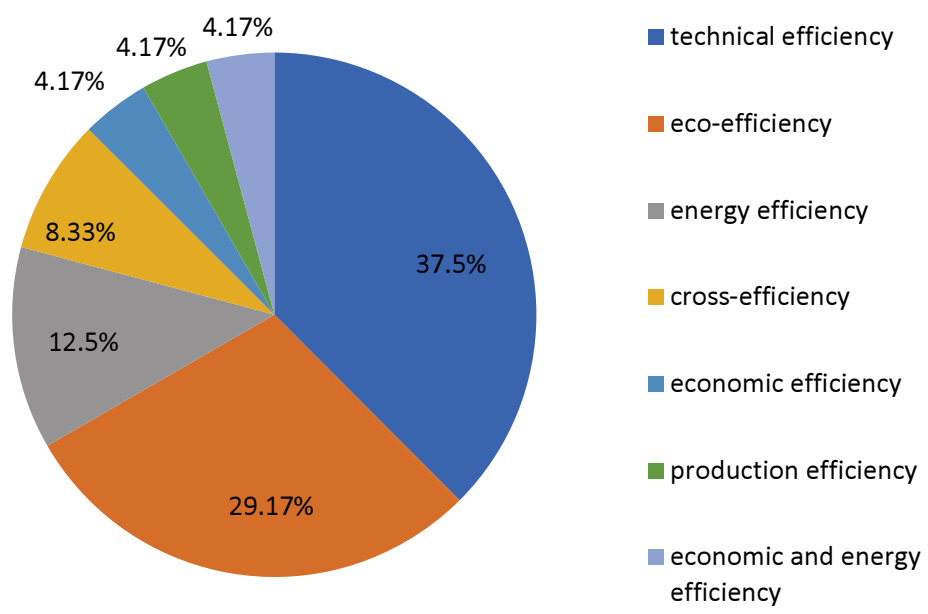

Figure 3: Distribution of efficiency type solved by DEA method

Nine papers presented in table 6 examine the technical efficiency (9 out of 24) and seven papers examine the eco-efficiency (7 out of 24). These two types of efficiency measures are the most common efficiency measures that are solved in published papers in the agricultural land processing area. Other types of efficiency measures (energy, cross-efficiency, economic, production and some combinations) are represented in $33.33 \%$ (8 papers out of 24$)$.

\section{Overview of Other OR Methods Used in Agricultural Land Processing}

Agricultural problems are often very complex and could only be modelled by non linear programming. They also include more than one criterion, so the multi objective optimization is used for these problems.

Table 7: Overview of other OR methods in agricultural land processing

\begin{tabular}{|c|c|c|}
\hline Reference & Problem & Model \\
\hline $\begin{array}{l}\text { Luqman, Saeed, Ali, Tabassam \& } \\
\text { Mahmood, } 2019\end{array}$ & crop rotation in organic farming & $\begin{array}{l}\text { linear and nonlinear } \\
\text { programming }\end{array}$ \\
\hline West, 2019 & crop rotation problem in horticulture & multicriteria optimization \\
\hline Utamima, Reiners \& Ansaripoor, 2019 & agricultural routing planning & $\begin{array}{l}\text { binary integer programing } \\
\text { model }\end{array}$ \\
\hline Boyabatli, Nasiry \& Zhou, 2019 & $\begin{array}{l}\text { allocation of farmland among multiple crops in } \\
\text { each growing season }\end{array}$ & dynamic programming \\
\hline $\begin{array}{l}\text { Andric Gusavac, Stanojevic \& } \\
\text { Cangalovic, } 2019\end{array}$ & agricultural land treatment using aviation & $\begin{array}{l}\text { mixed integer mathematical } \\
\text { programming model }\end{array}$ \\
\hline Carvajal, Sarache \& Costa, 2019 & $\begin{array}{l}\text { crop planning; strategic and tactical planning } \\
\text { in sugarcane supply chain }\end{array}$ & $\begin{array}{l}\text { linear programming, } \\
\text { stochastic optimization }\end{array}$ \\
\hline Udias et al., 2018 & $\begin{array}{l}\text { increase agricultural growth by identification } \\
\text { and selection of optimal agricultural strategies }\end{array}$ & multiobjective optimization \\
\hline Dunnett et al., 2018 & $\begin{array}{l}\text { land use allocation in order to prioritize } \\
\text { agriculture interventions }\end{array}$ & multiobjective optimization \\
\hline Aljanabi et al. 2018 & crop planning and allocation of waste water & $\begin{array}{l}\text { mixed-integer nonlinear } \\
\text { programming }\end{array}$ \\
\hline Vasu et al., 2018 & $\begin{array}{l}\text { identification of soil characteristics and } \\
\text { assessment of the suitability of the soil for } \\
\text { crop planting }\end{array}$ & $\begin{array}{l}\text { multicriteria evaluation of } \\
\text { land suitability }\end{array}$ \\
\hline
\end{tabular}




\begin{tabular}{|c|c|c|}
\hline Reference & Problem & Model \\
\hline Talukder, Hipel \& van Loon, 2018 & $\begin{array}{l}\text { assessment of the sustainability of agricultural } \\
\text { systems }\end{array}$ & multi-criteria decision analysis \\
\hline locola et al., 2018 & $\begin{array}{l}\text { assessment of the sustainability of organic } \\
\text { vegetable production }\end{array}$ & multi criteria analysis \\
\hline Musakwa, 2018 & $\begin{array}{l}\text { identification of land suitable for } \\
\text { implementation of agricultural reforms }\end{array}$ & $\begin{array}{l}\text { geo-information systems, } \\
\text { multi-criteria decision analysis }\end{array}$ \\
\hline Qureshi, Singh \& Hasan, 2018 & $\begin{array}{l}\text { crop planning for sustainable agricultural } \\
\text { production }\end{array}$ & $\begin{array}{l}\text { fuzzy multicriteria decision } \\
\text { making }\end{array}$ \\
\hline Ma, Zhang, Ma, Fan \& Zhao, 2018 & $\begin{array}{l}\text { production and operation scheduling in wheat } \\
\text { harvesting operation }\end{array}$ & dynamic programming \\
\hline Nuppenau, 2018 & crop rotation problem & dynamic programming \\
\hline Kung, 2018 & $\begin{array}{l}\text { sustainable development of agriculture } \\
\text { framework }\end{array}$ & dynamic programming \\
\hline $\begin{array}{l}\text { Cobo, Dominguez-Ramos \& Irabien, } \\
2018\end{array}$ & $\begin{array}{l}\text { development of system efficiency indicators in } \\
\text { extending the lifetime of organic waste }\end{array}$ & $\begin{array}{l}\text { multiobjective mixed integer } \\
\text { linear programming model }\end{array}$ \\
\hline Mosleh et al., 2017 & $\begin{array}{l}\text { crop planning on suitable cultivable lands, } \\
\text { allocation of arable land and water resources }\end{array}$ & goal programming model \\
\hline Priya \& Geetha, 2017 & $\begin{array}{l}\text { optimization of agricultural resources (water, } \\
\text { fertilizer, micronutrients) for plant growing }\end{array}$ & $\begin{array}{l}\text { dynamic programming, } \\
\text { dynamic resource } \\
\text { minimization algorithm }\end{array}$ \\
\hline $\begin{array}{l}\text { Afzal, Naeem, lqbal, Sharif \& Huang, } \\
2017\end{array}$ & $\begin{array}{l}\text { allocation of energy resources in agricultural } \\
\text { production }\end{array}$ & integer programming model \\
\hline Srivastava \& Singh, 2017 & allocation of agricultural land to crops & $\begin{array}{l}\text { fuzzy multiobjective-based } \\
\text { goal programming model }\end{array}$ \\
\hline Filippi, Mansini \& Stevanato, 2017 & crop mix selection & $\begin{array}{l}\text { mixed integer linear } \\
\text { programming, conditional } \\
\text { Value-at-Risk }\end{array}$ \\
\hline $\begin{array}{l}\text { Galan-Martín, Vaskan, Antón, Esteller } \\
\text { \& Guillén-Gosálbez, } 2017\end{array}$ & $\begin{array}{l}\text { crops planning; allocation of rainfed and } \\
\text { irrigated arable land }\end{array}$ & $\begin{array}{l}\text { multiobjective linear } \\
\text { programming model }\end{array}$ \\
\hline $\begin{array}{l}\text { Talukder, Blay-Palmer, Hipel \& van } \\
\text { Loon, } 2017\end{array}$ & $\begin{array}{l}\text { assessment of sustainability of different } \\
\text { agricultural systems }\end{array}$ & multicriteria decision analysis \\
\hline Jana, Sharma \& Chakraborty, 2016 & agricultural production planning & fuzzy goal programming \\
\hline $\begin{array}{l}\text { Bueno-Delgado, Molina-Martínez, } \\
\text { Correoso-Campillo \& Pavón-Mariño, } \\
2016\end{array}$ & $\begin{array}{l}\text { Android application for the problem of fertilizer } \\
\text { selection for agricultural production }\end{array}$ & $\begin{array}{l}\text { linear } \\
\text { programming }\end{array}$ \\
\hline Singh et al., 2016 & $\begin{array}{l}\text { review; allocation of groundwater and surface- } \\
\text { water resources for irrigation }\end{array}$ & $\begin{array}{l}\text { linear programming, nonlinear } \\
\text { programming, dynamic } \\
\text { programming, and genetic } \\
\text { algorithms }\end{array}$ \\
\hline St John et al., 2016 & $\begin{array}{l}\text { designing a deer migration corridor with } \\
\text { harvest planning }\end{array}$ & $\begin{array}{l}\text { mixed integer programming; } \\
\text { spatial optimization }\end{array}$ \\
\hline $\begin{array}{l}\text { Montgomery, Dragicevic, Dujmovic \& } \\
\text { Schmidt, } 2016\end{array}$ & $\begin{array}{l}\text { evaluation of the capability and suitability of } \\
\text { land for agricultural production }\end{array}$ & $\begin{array}{l}\text { geo-information systems, soft } \\
\text { computing }\end{array}$ \\
\hline Cabrini \& Calcaterra, 2016 & $\begin{array}{l}\text { land allocation to crops: evaluation of the } \\
\text { economic and environmental impacts }\end{array}$ & compromise programming \\
\hline Diban et al., 2016 & $\begin{array}{l}\text { optimization of biomass plantation replanting } \\
\text { policy }\end{array}$ & dynamic programming \\
\hline Alfandari, Plateau \& Schepler, 2015 & sustainable crop rotation planning & integer programming \\
\hline $\begin{array}{l}\text { Baglivi, Fiorese, Guariso \& Uggè, } \\
2015\end{array}$ & allocation of agricultural land to crops & $\begin{array}{l}\text { multiobjective nonlinear } \\
\text { programming }\end{array}$ \\
\hline
\end{tabular}

It is interesting to see agricultural problem types that are solved by OR methods other than LP and compare these types with problem types solved by LP (presented in Figure 2). Problems related to the processing of agricultural land solved presented in Table 7 can be grouped into seven categories: crop planning, crop rotation, other problems, sustainability and sustainable development in agriculture area, resource (energy, water, biomass) planning, harvesting problems, allocation of agricultural land, routing problem in agriculture. Distribution of these groups can be seen in Figure 4. 


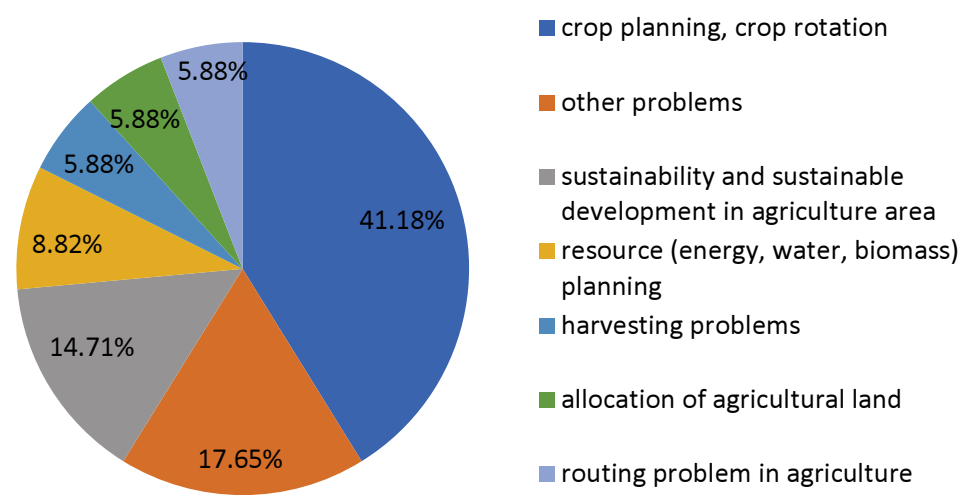

Figure 4 Distribution of agricultural problem types solved by other OR methods

Most of the analysed articles are dealing with crop planning and crop rotation problems (41.18\%). This is a very similar percentage as in LP solved problems shown in Figure 2. Harvesting problems and resource problems are also solved by LP (harvesting $7.41 \%$, resource $11.11 \%$ ) and other OR methods (harvesting $5.88 \%$, resource $8.82 \%)$.

Conslusion

The problems of agricultural land cultivation are successfully solved by the methods and techniques of operational research, and this paper gives an overview of problems solved by OR methods and techniques. It can be concluded that a large number of problems can be solved by linear programming, which is good, because these problems of large dimensions can be solved exactly, and the problems that occur in agriculture are always large-scale problems.

The papers included in a literature review cover the period of the last five years. The basic idea for this paper is to perceive a real impact of operations research methods and techniques implementation in the agricultural land processing. According to the above conducted analysis of the literature in this area, a total of 85 published articles are divided into three groups. The groups are formed according to methods used in modelling the problem. We perceived two groups: application of linear programming (27 articles) and application of DEA method ( 24 articles) in solving the agricultural land processing problems. Other OR methods applications (34 articles) are joined in the third group.

It is interesting that all of the articles (except Singh et al., 2016) are related to the application of the given methods to solving the agricultural land processing problems. Applications are very specific and this is the reason we have so many different keywords appearing in the articles. We noticed that "operations research" or "OR" does not appear in any article as a keyword, only "OR in agriculture" appears in two articles (Albornoz et al., 2019, Alfandari et al., 2015). The inclusion of such common keyword may result in afaster search in repositories of all articles.

\section{Acknowledgements}

Parts of this paper have been presented at the conference XLVI International Symposium on Operational Research - SYMOP-IS 2019. It has been selected as the best in the section.

\section{REFERENCES}

[1] Abbas A., Iqbal T., Ahmad M., Yousaf K., Elahi E., \& Yang M. (2018). Implementation of a novel approach for the evaluation of energy efficiency, management needs and sustainability of wheat production. Fresenius Environmental Bulletin 27,10, 6695-6703. DOI:

[2] Afzal M., Naeem M., lqbal M., Sharif M., \& Huang Q. (2017). Efficient energy resource scheduling for sustainable diversified farming. Journal of Renewable and Sustainable Energy 9,4, -. DOI:10.1063/1.4997031

[3] Ahodo K., Oglethorpe D., Hicks H.L., \& Freckleton R.P. (2019). Estimating the farm-level economic costs of spring cropping to manage Alopecurus myosuroides (black-grass) in UK agriculture. Journal of Agricultural Science 157,4, 318-332. DOI:10.1017/S0021859619000650

[4] Albornoz V.M., Nanco L.J., \& Saez J.L. (2019). Delineating robust rectangular management zones based on column generation algorithm. Computers and Electronics in Agriculture , -. DOI:10.1016/j.compag.2019.01.045 
[5] Alfandari L., Plateau A., \& Schepler X. (2015). A branch-and-price-and-cut approach for sustainable crop rotation planning. European Journal of Operational Research 241,3, 872-879. DOI:10.1016/j.ejor.2014.09.066

[6] Aljanabi A.A., Mays L.W., \& Fox P. (2018). Optimization model for agricultural reclaimed water allocation using mixed-integer nonlinear programming. Water (Switzerland) 10,10, -.

[7] Andric Gusavac B., \& Savic G. (2019, September). Overview of linear optimization problems and data envelopment analysis in agricultural land processing. Paper presented at the XLVI International Symposium on Operational Research SYMOPIS 2019.

[8] Andric Gusavac B., Stanojevic M., \& Cangalovic M. (2019). Optimal treatment of agricultural land special multi-depot vehicle routing problem. Agricultural Economics (Czech Republic) 65,12, 569-578. DOI:10.17221/134/2019-AGRICECON

[9] Atici K.B., \& Podinovski V.V. (2015). Using data envelopment analysis for the assessment of technical efficiency of units with different specialisations: An application to agriculture. Omega (United Kingdom) 54, 72-83. DOI:10.1016/j.omega.2015.01.015

[10] Baglivi A., Fiorese G., Guariso G., \& Ugge C. (2015). Valuing crop diversity in biodiesel production plans. Energy 93, 2351-2362. DOI:10.1016/j.energy.2015.10.080

[11] Bavorova M., Imamverdiyev N., \& Ponkina E. (2018). Farm-level economics of innovative tillage technologies: the case of no-till in the Altai Krai in Russian Siberia. Environmental Science and Pollution Research 25,2, 1016-1032. DOI:10.1007/s11356-017-9268-y

[12] Boboev H., Djanibekov U., Bekchanov M., Lamers J. P.A., \& Toderich K. (2019). Feasibility of conservation agriculture in the Amu Darya River Lowlands, Central Asia. International Journal of Agricultural Sustainability 17,1, 60-77. DOI:10.1080/14735903.2018.1560123

[13] Boyabatli O., Nasiry J., \& Zhou Y.H. (2019). Crop planning in sustainable agriculture: Dynamic farmland allocation in the presence of crop rotation benefits. Management Science 65,5, 2060-2076. DOI:10.1287/mnsc.2018.3044

[14] Bueno-Delgado M.V., Molina-Martínez J.M., Correoso-Campillo R., \& Pavón-Mariño P. (2016). Ecofert: An Android application for the optimization of fertilizer cost in fertigation. Computers and Electronics in Agriculture 121, 32-42. DOI:10.1016/j.compag.2015.11.006

[15] Cabrini S.M., \& Calcaterra C. P. (2016). Modeling economic-environmental decision making for agricultural land use in Argentinean Pampas. Agricultural Systems 143, 183-194. DOI:10.1016/j.agsy.2015.12.016

[16] Capitanescu F., Marvuglia A., Navarrete Gutiérrez T., \& Benetto E. (2017). Multi-stage farm management optimization under environmental and crop rotation constraints. Journal of Cleaner Production 147, 197205. DOI:10.1016/j.jclepro.2017.01.076

[17] Carvajal J., Sarache W., \& Costa Y. (2019). Addressing a robust decision in the sugarcane supply chain: Introduction of a new agricultural investment project in Colombia. Computers and Electronics in Agriculture 157, 77-89. DOI:10.1016/j.compag.2018.12.030

[18] Charnes, A., Cooper, W. W., \& Rhodes, E. (1978). A Data Envelopment Analysis Approach to Evaluation of the Program Follow through Experiment in US Public School Education (No. MSRR-432). CarnegieMellon Univ Pittsburgh Pa Management Sciences Research Group.

[19] Cid-Garcia N.M., \& Ibarra-Rojas O.J. (2019). An integrated approach for the rectangular delineation of management zones and the crop planning problems. Computers and Electronics in Agriculture 164,, . DOI:10.1016/j.compag.2019.104925

[20] Cobo S., Dominguez-Ramos A., \& Irabien A. (2018). Trade-Offs between Nutrient Circularity and Environmental Impacts in the Management of Organic Waste. Environmental Science and Technology 52,19, 10923-10933. DOI:10.1021/acs.est.8b01590

[21] Das B., Singh A., Panda S.N., \& Yasuda H. (2015). Optimal land and water resources allocation policies for sustainable irrigated agriculture. Land Use Policy 42, 527-537. DOI:10.1016/j.landusepol.2014.09.012

[22] Diban P., Abdul Aziz M.K., Foo D.C.Y., Jia X., Li Z., \& Tan R.R. (2016). Optimal biomass plantation replanting policy using dynamic programming. Journal of Cleaner Production 126, 409-418. DOI:10.1016/j.jclepro.2016.03.097

[23] Djokic D., Jurjevic Z., Popovic R., \& Savic M. (2019). Is there a correlation between economic and energy use efficiency in soybean production?. Custos e Agronegocio 15,2, 489-505. DOI:

[24] Dunnett A., Shirsath P.B., Aggarwal P.K., Thornton P., Joshi P.K., Pal B.D., Khatri-Chhetri A., \& Ghosh J. (2018). Multi-objective land use allocation modelling for prioritizing climate-smart agricultural interventions. Ecological Modelling 381, 23-35. DOI:10.1016/j.ecolmodel.2018.04.008

[25] Filippi C., Mansini R., \& Stevanato E. (2017). Mixed integer linear programming models for optimal crop selection. Computers and Operations Research 81, 26-39. DOI:10.1016/j.cor.2016.12.004

[26] Gadanakis Y., Bennett R., Park J., \& Areal F.J. (2015). Evaluating the Sustainable Intensification of arable farms. Journal of Environmental Management 150, 288-298. DOI:10.1016/j.jenvman.2014.10.005 
[27] Galan-Martín A., Pozo C., Guillén-Gosalbez G., Antón Vallejo A., \& Jimenez Esteller L. (2015). Multistage linear programming model for optimizing cropping plan decisions under the new Common Agricultural Policy. Land Use Policy 48, 515-524. DOI:10.1016/j.landusepol.2015.06.022

[28] Galan-Martín A., Vaskan P., Anton A., Esteller L.J., \& Guillen-Gosalbez G. (2017). Multi-objective optimization of rainfed and irrigated agricultural areas considering production and environmental criteria: a case study of wheat production in Spain. Journal of Cleaner Production 140, 816-830. DOI:10.1016/j.jclepro.2016.06.099

[29] Godoy-Durán A., Galdeano- Gomez E., Perez-Mesa J.C., \& Piedra-Munoz L. (2017). Assessing ecoefficiency and the determinants of horticultural family-farming in southeast Spain. Journal of Environmental Management 204, 594-604. DOI:10.1016/j.jenvman.2017.09.037

[30] Grados D., \& Schrevens E. (2019). Multidimensional analysis of environmental impacts from potato agricultural production in the Peruvian Central Andes. Science of the Total Environment 663, 927-934. DOI:10.1016/j.scitotenv.2019.01.414

[31] Guth M., \& Sm dzik-Ambro y K. (2019). Economic resources versus the efficiency of different types of agricultural production in regions of the European union. Economic Research-Ekonomska Istrazivanja. DOI:10.1080/1331677X.2019.1585270

[32] Herrera-Caceres C., Perez-Galarce F., Alvarez-Miranda E., \& Candia-Véjar A. (2017). Optimization of the harvest planning in the olive oil production: A case study in Chile. Computers and Electronics in Agriculture 141, 147-159. DOI:10.1016/j.compag.2017.07.017

[33] Iocola I., Campanelli G., Diacono M., Leteo F., Montemurro F., Persiani A., \& Canali S. (2018). Sustainability assessment of organic vegetable production using a qualitative multi-attribute model. Sustainability (Switzerland) 10,10, -. DOI:10.3390/su10103820

[34] Jana R.K., Sharma D.K., \& Chakraborty B. (2016). A hybrid probabilistic fuzzy goal programming approach for agricultural decision-making. International Journal of Production Economics 173, 134141. DOI:10.1016/j.ijpe.2015.12.010

[35] Jones, J. W., Antle, J. M., Basso, B., Boote, K. J., Conant, R. T., Foster, I., .. \& Keating, B. A. (2017). Brief history of agricultural systems modeling. Agricultural systems, 155, 240-254.

[36] Khanjarpanah H., Pishvaee M.S., \& Seyedhosseini S.M. (2017). A risk averse cross-efficiency data envelopment analysis model for sustainable switchgrass cultivation location optimization. Industrial Crops and Products 109, 514-522. DOI:10.1016/j.indcrop.2017.09.005

[37] Khoshroo A., Izadikhah M., \& Emrouznejad A. (2018). Improving energy efficiency considering reduction of $\mathrm{CO} 2$ emission of turnip production: A novel data envelopment analysis model with undesirable output approach. Journal of Cleaner Production 187, 605-615. DOI:10.1016/j.jclepro.2018.03.232

[38] Kiryluk-Dryjska E., \& Beba P. (2018). Region-specific budgeting of rural development funds-An application study. Land Use Policy 77, 126-134. DOI:10.1016/j.landusepol.2018.05.029

[39] Kobson. (2019). Serbian Consortium for Coordinated Acquisition of Electronic Resources. Retrieved from https://kobson.nb.rs/kobson.654.html

[40] Kocisova K. (2015). Application of the DEA on the measurement of efficiency in the EU countries. Agricultural Economics (Czech Republic) 61,2, 51-62. DOI:10.17221/107/2014-AGRICECON

[41] Kocjancic T., Debeljak M., Zgajnar J., \& Juvancic L. (2018). Incorporation of emergy into multiple-criteria decision analysis for sustainable and resilient structure of dairy farms in Slovenia. Agricultural Systems 164, 71-83. DOI:10.1016/j.agsy.2018.03.005

[42] Kong Q., Kuriyan K., Shah N., \& Guo M. (2019). Development of a responsive optimisation framework for decision-making in precision agriculture. Computers and Chemical Engineering 131,, -. DOI:10.1016/j.compchemeng.2019.106585

[43] Kung C.-C. (2018). A dynamic framework of sustainable development in agriculture and bioenergy. Agricultural Economics (Czech Republic) 64,10, 445-455. DOI:10.17221/281/2017-AGRICECON

[44] Li N., Jiang Y., Mu H., \& Yu Z. (2018). Efficiency evaluation and improvement potential for the Chinese agricultural sector at the provincial level based on data envelopment analysis (DEA). Energy 164, 11451160. DOI:10.1016/j.energy.2018.08.150

[45] Li Q., Hu G., \& Jubery T.Z., Ganapathysubramanian B. (2017). A farm-level precision land management framework based on integer programming. PLoS ONE 12,3, -. DOI:10.1371/journal. Pone.0174680

[46] Luqman M., Saeed M., Ali J., Tabassam M.F., \& Mahmood T. (2019). Targeted showering optimization: Training irrigation tools to solve crop planning problems. Pakistan Journal of Agricultural Sciences 56,1, 225-235. DOI:10.21162/PAKJAS/19.7910

[47] Ma L., Zhang Y., Ma M., Fan Y., \& Zhao H. (2018). Model of combine trans-regional operation scheduling. International Agricultural Engineering Journal 27,3, 52-60. DOI:

[48] Masuda K. (2018). Energy efficiency of intensive rice production in Japan: An application of data envelopment analysis. Sustainability (Switzerland) 10,1, -. DOI:10.3390/su10010120

[49] Masuda K. (2019). Eco-efficiency assessment of intensive rice production in Japan: Joint application of life cycle assessment and data envelopment analysis. Sustainability (Switzerland) 11,19, -. DOI:10.3390/su11195368 
[50] Mirza F.M., Najam N., Mehdi M., \& Ahmad B. (2015). Determinants of technical efficiency of wheat farms in Pakistan. Pakistan Journal of Agricultural Sciences 52,2, 577-582. DOI:

[51] Montgomery B., Dragicevic S., Dujmovic J., \& Schmidt M. (2016). A GIS-based Logic Scoring of Preference method for evaluation of land capability and suitability for agriculture. Computers and Electronics in Agriculture 124, 340-353. DOI:10.1016/j.compag.2016.04.013

[52] Mosleh Z., Salehi M.H., Amini Fasakhodi A., Jafari A., Mehnatkesh A., \& Esfandiarpoor Borujeni I. (2017). Sustainable allocation of agricultural lands and water resources using suitability analysis and mathematical multi-objective programming. Geoderma 303, 52-59. DOI:10.1016/j.geoderma.2017.05.015

[53] Moutinho V., Madaleno M., Macedo P., Robaina M., \& Marques C. (2018). Efficiency in the European agricultural sector: environment and resources. Environmental Science and Pollution Research 25,18, 17927-17941. DOI:10.1007/s11356-018-2041-z

[54] Muhtarom A., Haryanto T., \& Istifadah N. (2019). Analysis of productivity efficiency of food plant agriculture in East Java based on DEA index. International Journal of Civil Engineering and Technology 10,1, 420-443. DOI:

[55] Murtaza G., \& Thapa G.B. (2017). Factors affecting technical efficiency of small-scale apple farms in Balochistan Plateau, Pakistan. Journal of Mountain Science 14,4, 782-794. DOI:10.1007/s11629-0163937-z

[56] Musakwa W. (2018). Identifying land suitable for agricultural land reform using GIS-MCDA in South Africa. Environment, Development and Sustainability 20,5, 2281-2299. DOI:10.1007/s10668-017-9989-6

[57] Naudin K., Bruelle G., Salgado P., Penot E., Scopel E., Lubbers M., de Ridder N., \& Giller K.E. (2015). Trade-offs around the use of biomass for livestock feed and soil cover in dairy farms in the Alaotra lake region of Madagascar. Agricultural Systems 134, 36-47. DOI:10.1016/j.agsy.2014.03.003

[58] Nidumolu U.B., Lubbers M., Kanellopoulos A., van Ittersum M.K., Kadiyala D.M., \& Sreenivas G. (2016). Engaging farmers on climate risk through targeted integration of bio-economic modelling and seasonal climate forecasts. Agricultural Systems 149, 175-184. DOI:10.1016/j.agsy.2016.09.011

[59] Nowak A., Kijek T., \& Domanska K. (2015). Technical efficiency and its determinants in the European Union agriculture. Agricultural Economics (Czech Republic) 61,6, 275-283. DOI:10.17221/200/2014AGRICECON

[60] Nuppenau E.-A. (2018). Soil fertility management by transition matrices and crop rotation: On spatial and dynamic aspects in programming of ecosystem services. Sustainability (Switzerland) 10,7, - . DOI:10.3390/su10072213

[61] Pieralli S. (2017). Introducing a new non-monotonic economic measure of soil quality. Soil and Tillage Research 169, 92-98. DOI:10.1016/j.still.2017.01.015

[62] Pokhrel A., \& Soni P. (2017). Performance analysis of different rice-based cropping systems in tropical region of Nepal. Journal of Environmental Management 197, 70-79. DOI:10.1016/j.jenvman.2017.03.035

[63] Prisenk J., Turk J., Rozman C., Borec A., Zrakic M., \& Pazek K. (2014). Advantages of combining linear programming and weighted goal programming for agriculture application. Operational Research 14,2, 253-260. DOI:10.1007/s12351-014-0159-4

[64] Prisenk J., Vincec J., Pavic L., Rozman C., Turk J., \& Pazek K. (2019). Cropping-plan optimization on agricultural holdings with a combination of linear and weighted-goal programming. Applied Engineering in Agriculture 35,1, 109-116. DOI:10.13031/aea.13138

[65] Priya N., \& Geetha G. (2017). Dynamic programming based resource optimization in agricultural big data for crop yield maximization. Journal of Computational and Theoretical Nanoscience 14,9, 44644470. DOI:10.1166/jctn.2017.6762

[66] Qureshi M.R.N., Singh R.K., \& Hasan M.A. (2018). Decision support model to select crop pattern for sustainable agricultural practices using fuzzy MCDM. Environment, Development and Sustainability 20,2, 641-659. DOI:10.1007/s10668-016-9903-7

[67] Rocco C.D., \& Morabito R. (2016). Production and logistics planning in the tomato processing industry: A conceptual scheme and mathematical model. Computers and Electronics in Agriculture 127, 763774. DOI:10.1016/j.compag.2016.08.002

[68] Rybaczewska-Błazejowska M., \& Gierulski W. (2018). Eco-efficiency evaluation of agricultural production in the EU-28. Sustainability (Switzerland) 10,12, -. DOI:10.3390/su10124544

[69] Singh A. (2015). Land and water management planning for increasing farm income in irrigated dry areas. Land Use Policy 42, 244-250. DOI:10.1016/j.landusepol.2014.08.006

[70] Singh A. (2017). Optimal allocation of water and land resources for maximizing the farm income and minimizing the irrigation-induced environmental problems. Stochastic Environmental Research and Risk Assessment 31,5, 1147-1154. DOI:10.1007/s00477-016-1326-3

[71] Singh A., Panda S.N., Saxena C.K., Verma C.L., Uzokwe V.N.E., Krause P., \& Gupta S.K. (2016). Optimization modeling for conjunctive use planning of surface water and groundwater for irrigation. Journal of Irrigation and Drainage Engineering 142,3, -. DOI:10.1061/(ASCE)IR.1943-4774.0000977 
[72] Smith L.G., Jones P.J., Kirk G.J.D., Pearce B.D., \& Williams A.G. (2018). Modelling the production impacts of a widespread conversion to organic agriculture in England and Wales. Land Use Policy 76, 391-404. DOI:10.1016/j.landusepol.2018.02.035

[73] Souza G.D.S., \& Gomes E.G. (2015). Improving agricultural economic efficiency in Brazil. International Transactions in Operational Research 22,2, 329-337. DOI:10.1111/itor.12055

[74] Srivastava P., \& Singh R.M. (2017). Agricultural land allocation for crop planning in a canal command area using fuzzy multiobjective goal programming. Journal of Irrigation and Drainage Engineering 143,6, -. DOI:10.1061/(ASCE)IR.1943-4774.0001175

[75] St John R., Öhman K., Tóth S.F., Sandström P., Korosuo A., \& Eriksson L.O. (2016). Combining spatiotemporal corridor design for reindeer migration with harvest scheduling in Northern Sweden. Scandinavian Journal of Forest Research 31,7, 655-663. DOI:10.1080/02827581.2016.1195441

[76] Staniszewski J. (2018). Attempting to measure sustainable intensification of agriculture in countries of the European Union. Journal of Environmental Protection and Ecology 19,2, 949-957. DOI:

[77] Talukder B., Blay-Palmer A., Hipel K.W., \& vanLoon G.W. (2017). Elimination method of multi-criteria decision analysis (MCDA): A simple methodological approach for assessing agricultural sustainability. Sustainability (Switzerland) 9,2, -. DOI:10.3390/su9020287

[78] Talukder B., Hipel K.W., \& vanLoon G.W. (2018). Using multi-criteria decision analysis for assessing sustainability of agricultural systems. Sustainable Development 26,6, 781-799. DOI:10.1002/sd.1848

[79] Toma P., Miglietta P. P., Zurlini G., Valente D., \& Petrosillo I. (2017). A non-parametric bootstrap-data envelopment analysis approach for environmental policy planning and management of agricultural efficiency in EU countries. Ecological Indicators 83, 132-143. DOI:10.1016/j.ecolind.2017.07.049

[80] Udias A., Pastori M., Dondeynaz C., Carmona Moreno C., Ali A., Cattaneo L., \& Cano J. (2018). A decision support tool to enhance agricultural growth in the Mékrou river basin (West Africa). Computers and Electronics in Agriculture 154, 467-481. DOI:10.1016/j.compag.2018.09.037

[81] Utamima A., Reiners T., \& Ansaripoor A.H. (2019). Optimisation of agricultural routing planning in field logistics with Evolutionary Hybrid Neighbourhood Search. Biosystems Engineering 184,, 166-180. DOI:10.1016/j.biosystemseng.2019.06.001

[82] Vasu D., Srivastava R., Patil N.G., Tiwary P., Chandran P., \& Kumar Singh S. (2018). A comparative assessment of land suitability evaluation methods for agricultural land use planning at village level. Land Use Policy 79, 146-163. DOI:10.1016/j.landusepol.2018.08.007

[83] Vlontzos G., Niavis S., \& Pardalos P. (2017). Testing for environmental Kuznets curve in the EU agricultural sector through an Eco-(in)efficiency index. Energies 10,12, -. DOI:10.3390/en10121992

[84] Ward J.D., Ward P.J., Mantzioris E., \& Saint C. (2014). Optimising diet decisions and urban agriculture using linear programming. Food Security 6,5, 701-718. DOI:10.1007/s12571-014-0374-0

[85] Weintraub, A., \& Romero, C. (2006). Operations research models and the management of agricultural and forestry resources: a review and comparison. Interfaces, 36(5), 446-457.

[86] West J. (2019). Multi-criteria evolutionary algorithm optimization for horticulture crop management. Agricultural Systems 173,, 469-481. DOI:10.1016/j.agsy.2019.03.016

[87] You P.-S., \& Hsieh Y.-C. (2017). A computational approach for crop production of organic vegetables. Computers and Electronics in Agriculture 134, 33-42. DOI:10.1016/j.compag.2016.11.003

[88] Zhang C., Li M., \& Guo P. (2017). Two-stage stochastic chance-constrained fractional programming model for optimal agricultural cultivation scale in an arid area. Journal of Irrigation and Drainage Engineering 143,9, -. DOI:10.1061/(ASCE)IR.1943-4774.0001216

[89] Zhang X., Jiang L., Qiu X., Qiu J., Wang J., \& Zhu Y. (2016). An improved method of delineating rectangular management zones using a semivariogram-based technique. Computers and Electronics in Agriculture 121, 74-83. DOI:10.1016/j.compag.2015.11.016

[90] Zhong J., Yu T.E., Clark C.D., English B.C., Larson J.A., \& Cheng C.-L. (2018). Effect of land use change for bioenergy production on feedstock cost and water quality. Applied Energy 210, 580-590. DOI:10.1016/j.apenergy.2017.09.070

Received: 2020-03-20

Revision requested: 2020-06-19

Revised: 2020-07-01

Accepted: 2020-07-06 


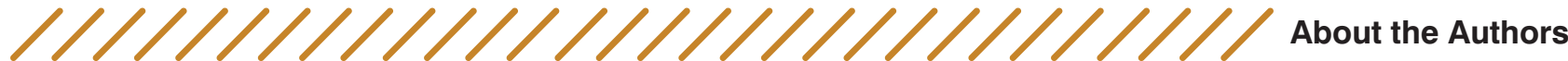

\author{
Bisera Andrić Gušavac \\ University of Belgrade, Faculty of Organizational Sciences, \\ Laboratory of Operational Research "Jovan Petrić", Serbia \\ bisera.andric.gusavac@fon.bg.ac.rs
}

Bisera Andrić Gušavac is a PhD candidate working at the of Operational Research "Jovan Petrić" at the University of Belgrade, Faculty of Organizational Sciences. She has a degree in Specialized Master of Industrial Engineering organized by the prestigious French faculty École Centrale Paris, as a scholarship holder of the French government. Her research interests include mathematical modelling, optimization, industrial engineering and performance analytics. Bisera Andrić Gušavac is an author or coauthor of more than 40 scientific and research papers. She was a member of the project teams in four national and international research projects and has been active in organizing scientific conferences (BALCOR; SYM-OP-IS and SymOrg).

\section{Gordana Savić}

University of Belgrade, Faculty of Organizational Sciences, Laboratory of Operational Research "Jovan Petrić", Centre for Efficiency Analysis, Serbia gordana.savic@fon.bg.ac.rs

Gordana Savić is an Associate professor in the Operational Research, Performance and Business Analytics at the University of Belgrade, Faculty of Organizational Sciences and Faculty of Agriculture. She received a PhD degree in Operations Research from the University of Belgrade, Faculty of Organizational Sciences in 2012. She is head of Laboratory for Operational Research and Centre for Efficiency Analysis. Her research interests include mathematical modelling, optimization, business and performance analytics. Gordana is an author or co-author of more than 100 scientific and research papers. Out of them, more than 25 are monograph chapters and papers in leading scientific journals including European Journal of Operational Research, Expert Systems with Application, Higher Education and Scientometrics. She is a member of the project teams in more than ten national and international projects and participant in several research projects. She also was a participant, coordinator, or leader of a wide range of practical projects in the fields of ICT consulting, performance analytics, mathematical modelling and optimization. Gordana serves as a reviewer, editor and guest editor in several leading international and national journals. Furthermore, she has been active in organizing scientific conferences as chair of organizing and member of scientific and organizing committees (BALCOR; SYM-OP-IS and SymOrg).
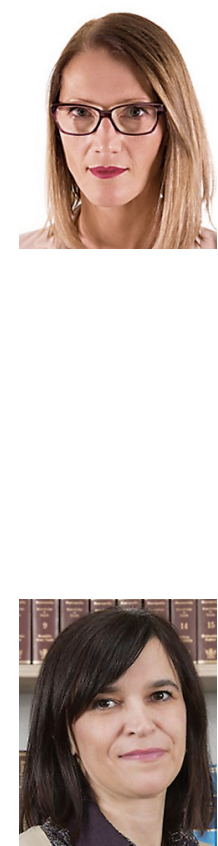